\title{
ADMINISTRATIVAS
}

\section{Participação da América Latina no Instituto de Ciências Administrativas}

A Administrativas se faz através dos respectivos Governos, ou de Seções $\mathrm{Na}$ cionais, ou, ainda, de membros individuais ou coletivos. As duas primeiras formas de participação não se excluem, ao contrário, se completam: um país pode, simultâneamente, ser Estado Membro e possuir Seção Nacional. Ser Estado Membro significa uma participação direta do Govêrno respectivo no Instituto, ter Seção Nacional quer dizer possuir um organismo permanente que, por delegação do IICA, o represente para todos os fins, no país, efetuando pesquisas, elaborando publicações, organizando documentação, promovendo conferências e cursos, prestando assistência técnica e exercendo outras atividades correlatas, tudo no campo das ciências administrativas. Quanto aos membros individuais ou coletivos, existem em paises onde não há Seção Nacional.

Atualmente, o IICA mantém contatos com 64 países, na sua maioria Estados Membros. As Seções Nacionais eram em número de 28 no ano próximo findo.

A América Latina tem uma representação diminuta no IICA. Apenas o México, o Chile e Honduras - além do Brasil - são Estados Membros ou possuem Seção Nacional (o Brasil é Estado Membro e possui Seção Nacional). Dos demais países latino-americanos, a Argentina, o Paraguai e o Uruguai possuiam, em 1959. um membro individual, cada um, e a Colombia, dois.

Essa situação preocupa a Seção Nacional Brasileira - o Instituto Brasileirc de Ciências Administrativas - desde a sua instalação, tendo em vista a especial relevância das teorias, técnicas e práticas administrativas para os povos que. como os dêste continente, estão em processo de aceleração de seit desenvolvimento econômico.

Assim, vinha o Instituto estudando os meios pelos quais the fôsse possivel contribuir para despertar em nossos irmãos do continente maior interêsse por uma associação efetiva as nações que, no IICA, batalham pelo aperfeiçoamento das tecrias, técnicas e práticas administrativas.

Com êsse objetivc. ofereceu a Diretoria do IBCA, em dezembro último, seus préstimos ao IICA para tomar mais conhecidos na América Latina os objetivos e as atividades do Instituto de obter a adesã odos respectivos Governos ao IICA e, ainda, a criação de Seções Nacionais em países do continente que não a possuem. 
A proposta do IBCA toi prontamente aceita pelo IICA, que nos enviou um completo dossier sôbre o estágio atual das relações que mantém na América Latina.

A oportunidade para o início de gestões efetivas no sentido de concretização da proposta brasileira surgiu por iniciativa do IICA, que convidou - D. Luiz Simões Lopes, Presidente do IBCA, para representá-lo na "Exposição Internacional de Livros e Periódicos», a realizar-se em La Plata, Argentina, sob os auspícios do Instituto Superior de Ciências Administrativas da Faculdade de Ciências Econômicas de La Plata, no mês de maio do corrente ano.

Tendo sido também convidado pelo Instituto promotor da exposição para pronunciar uma conferência sôbre Administração Pública, como parte do programa dáa referida Exposição, c Presidente do IBCA, aceitando ambas as incumbências, iniciou um programa de visitas às repúblicas da Argentina, Chile, Paraguai e Uruguai.

Graças, em parte, ao decisivo apoio do Govêrno Brasileiro, através de suas missões diplomáticas, desempenhou-se o Dr. Luiz Simões Lopes com inegável êxito de sua missão no sentido de ampliar a participação dos países latino-americanos no IICA.

$\mathrm{Na}$ Argentina, em companhia do Embaixador Fragoso, foi recebido pelo Ministro das Relações Exteriores e demais autoridades que deveriam opinar sôbre a adesão da Argentina ao IICA. Expostos os motivos que levaram o IICA, por intermédio de um de seus Vice-Presidentes e Presidente do IBCA, a fazer tal sugestão, e as vantagens que adviriam para o país ao ingressar como Estado Membro do Instituto, foi excelente a acolhida à idéia .

Igual êxito foi obtido no tocante à criação da Seção Nacional Argetina do IIC.A. Os contatos com o eminente mestre Rafael Bielsa, o Professor Linares Quintana e outros professôres e autoridades possibilitavam aguardar-se, para breve, a fundação da Seção Nacional do IICA naquele país.

Mais cêdo ainda do que esperava, teve o IBCA a grata notícia da fundação solene do Instituto Argentino de Ciências Administrativas, sob a presidência do professor Rafael Bielsa, conforme comunicação de 20 de julho. $\mathrm{O}$ rovo Instituto pleiteou: imeditamente seu reconhecimento como Seção $\mathrm{Na}$ cional Argentina do IICA.

Ainda na Argentina, compareceu o Presidente do IBCA à inauguração da Exposição acima mencionada e pronunciou uma conferência sôbre «Reforma Administrativa no Brasil», em que focalizou as principais medidas tomadas pelo Govêrno da República desde 1936 para racionalizar o mecanismo administrativo federal.

No Chile, para onde seguiu o Dr. Simões Lopes, apezar dos imensos problemas decorrentes do cataclisma que tão duramente atingia o país, foi igualmente calorosa a recepção proporcionada ao Presidente do IBCA.

Com a ajuda do Embaixador do Brasil, Dr. Rubens de Melo, entrou - Presidente do IBCA em contato com o Diretor da Escola de Administração, Dr. Jorge Gusman Dinator, e outros entusiastas da idéia de maior colaboração com o IICA. 
Ficou esclarecido que a Seção Nacional Chilena já estava em organização, desde 1959, faltando algumas providências finais.

Testemunhando seu aprêço pela visita do delegado do IICA, resolveram os chilenos instalar imediatamente a referida Seção, para o que foi convocad r uma assembléia dos interessados, que se realizou na sede da Escola de Ciências Políticas e Administrativas. Instalou-se, assim, a Seção Nacional Chilena do IICA, sob a presidência do mais alto funcionário do país, o «Contralor General». Fazem parte da nova organização vários ex-alunos da Escola Brasileira de Administração Pública, da Fundação Getúlio Vargas.

Seguiu o Dr. Simões Lopes para o Paraguai, onde, em companhia do Embaixador Marechal Zenóbio da Costa, foi recebido pelo Ministro das Relações Exteriores e outras autoridades. Focalizada a adesão do Paraguai ao IICA, foi a proposta recebida com simpatia, havendo o Ministro salientado seu especial agrado pelo fato de vir a mesma apoiada pelo Brasil. As perspectivas de integração do Paraguai com Estado Membro do IICA são bastante favoráveis.

Quanto à criação da Seção Nacional Paraguai, também, foi, em princípio decidida, com a colaboração do Diretor da Escola Paraguaia de Adnistração Pública, Dr. Fernando José Ayala, e do sócio do IICA naquele país, Dr. Peña Villamil.

Relativamente ao Uruguai, não se realizou, conforme planejado, o entendimento direto entre o Presidente do IBCA e o Ministro das Relações Exteriores, pois que êste viajara para a Argentina a fim de assistir aos festejos comemorativos do sesquicentenário da Revolução de Maio. Mas o Dr. Simões Lopes preparou documentação referente ao ingresso do Govêrno do Uruguai como Estado Membro do IICA e também destinada a provocar interêsse pela fundação da Seção Nacional Uruguaia, documentação essa a ser entregue pelo Embaixador do Brasil em Montevidéu, Dr. Walder Sarmanho, ao Govêrno Uruguaio.

Tudo indica, pois, que brevemente estará o Brasil acompanhado, nas. reuniões do IICA, dêsses países irmãos latino-americanos. 